\title{
SOME REMARKS ON THE ROMAN NECROPOLISES OF POTAISSA ${ }^{1}$
}

\begin{abstract}
In this paper are analysed the two Roman necropolises of Potaissa (modern day Turda, Cluj County, Romania) in order to establish a general overview of the burial spaces. Even if the Roman graves are found here beginning with the $19^{\text {th }}$ century, there is no study focused strictly on the issues regarding the burialscapes of the funerary areas. This article synthetize the current state of things and outlines some important aspects about the physical boundaries and the chronology of the abovementioned necropolises. By analysing all the grave clusters found beginning with 1894 until 2014 the author tried to illustrate the particularities and the general character of Potaissa's burial places as much as the state of information allowed.

Keywords: Potaissa; funerary archaeology; burialscape; Roman graves
\end{abstract}

$\mathbf{R}$ ight after the Roman conquest of 106 A.D., on the territory of nowadays Turda (Cluj County, Romania) a rural settlement was founded by a nucleus of colonists². The first epigraphic record of Patavissensium vicus, as Ulpianus names this settlement in Digestae ${ }^{3}$ is the milestone discovered in Aiton, near Turda ${ }^{4}$. The milestone is dated in 108 A.D.

In 169 A.D. legio VMacedonica was moved at Potaissa, ${ }^{5}$ where they built the castra legionis from "Dealul Cetății", the headquarters of the legionary unit until the Aurelian period. From now on, a second civil settlement is theoretically attested at Potaissa: canabae legionis V Macedonicae.

As we can see, there are three coexisting communities within the same area: a distinct military community formed by the soldiers of legio $V$ Macedonica beginning with 169 A.D., a community concentrated in cannabae legionis who's existence begins also in 169 A.D. and a separate community within the Patavissensium vicus, the later municipium Septimium Potaissense ${ }^{6}$ (after 197 A.D.).

Theoretically, within these three communities there must be three distinct necropolises ${ }^{7}$ assigned to each community, but as we will see further, the case of Potaissa brings into question some issues regarding the real ${ }_{1}$ I express my gratitude towards my tutor, Lecturer Sorin Nemeti from 'Babeș-Bolyai' University of Cluj-Napoca for his guidance, advice and for all the literature provided during my B.A. studies.

2 BĂRBULESCU 39-37, 1994

3 ULPIANUS, Digestae 50.15.1.9

4 CIL III 1627 Text:"Imp(erator)/ Caesar Nerva/ Traianus Aug(ustus)/ Germ(anicus) Dacicus/ pontif(ex) maxim(us)/[tribunicia] (pot(estate) XII co(n)s(ul) V/ imp(erator) VI p(ater) p(atriae) fecit/ per coh(ortem) I Fl(aviam) Vlp(iam)/ Hisp(anam) mil(liariam) c(ivium) R(omanorum) eq(uitatam)/ a Potaissa Napo/cam / m(ilia) p(assuum) X

5 BĂRBULESCU 1987 passim

${ }^{6}$ For a recent discution about the municipal status of Potaissa see NEMETI 2014, 85-88 and PISO 2014, 69-76

7 TOYNBEE $1971,, 73$

\section{Horațiu Cocis}

University 'Babeș-Bolyai' of Cluj-Napoca hcocis@yahoo.com

DOI: $10.14795 /$ j.v2i 2.115

ISSN 2360 - 266X

ISSN-L 2360 - 266X 
boundaries of the physicallandscapes of studied necropolises. The ruins of castra legionis and the Roman city drew attention of the scholars beginning with the $16^{\text {th }}$ century ${ }^{8}$, drawings and descriptions made by them representing especially the elevations of walls and the gates of the military base.

However, the Roman graves are discovered and published only since the $19^{\text {th }}$ centuryby the famous Hungarian scholar, István Téglás. Yet, it is important to mention that the first scholar who published Roman graves from Potaissa was Téglási Ercsey József (1792-1868) in Nemzeti Társalgó/ 1837. ${ }^{9}$ In 1894-1895, István Téglás and Gyula Volensky discovered another series of graves. ${ }^{10}$ Another big group of graves was discovered in 1906 by the same I. Téglás. ${ }^{11}$

Besides these graves published in Archeologiai Értesitő, the Hungarian scholar (I. Téglás) recorded in his sketches notebooks Roman graves found in $1894^{12}, 1902^{13}$, $1904^{14}, 1905,1906^{15}, 1907,1911$ and $1912 .^{16}$

The Romanian archaeologist began to discover and publish Roman graves within $1941 .{ }^{17}$ In $1956-1957$ another important group is found ${ }^{18}$, discoveries continuing also in $1964^{19}, 1969^{20}, 1978^{21}$ and $1985^{22}$. In $2002^{23}, 2006^{24}$ and 2014 were discovered the last Roman graves within the territory of Potaissa. We will analyse later each distinctive group.

As a general fact, we must underline that none of these graves were found during a systematic archaeological excavations but only by accident, agricultural activities, landslides, civil works or rescue excavations. For the majority of the graves or grave clusters we do not have a general plan (especially for the clusters found in $19^{\text {th }}$ century and in early $20^{\text {th }}$ century) or a terrain/situational positioning.

A database of all the Roman graves discovered at Potaissa was created for my B.A. Thesis and it is representing the starting point for this study. In order to get a clearly overview of the funerary spaces, firstly we have to analyse distinctively all the grave clusters (as much as the information allow us). We will start the discussion with the funerary area situate North of Arieș River.

\section{The first necropolis}

1. "Șuia" Hill.

"Șuia” Hill is located west of castra legionis on the left bank of Arieș River. Between 1951 and 1957 were discovered

\footnotetext{
8 BĂRBULESCU 13,1994

BALÁSZ 1889, 48

10 VOLENSKY 1895, 72-73; TÉGLÁS 1896, 65-68

BAJUSZ 2005, 775

BĂRBULESCU 86 1994; CĂTINAȘ 98-89,2011

BAJUSZ et all. 2005, 855-856; see also TÉGLÁS 1904, 410-413

BAJUSZ et all. 2005, 856

BAJUSZ et all. 2005, 886-887

BAJUSZ et all. 2005, 885, 893-894

RUSSU 1941, 333-338

ȚIGĂRA 1960, 200-202

MITROFAN 1969, 517-593

${ }^{20}$ MILEA/HOPÂRTEAN/LUCA 1978, 201-206; WOLSKA 1999, 244-255

21 LUCA/HOPÂRTEAN 1980, 115-122

22 BĂRBULESCU 89,1994

23 NEMETI/NEMETI 2014, 88-89

${ }^{24}$ PÎSLARU 364-339,2007
}

here seven graves ${ }^{25}$ (two graves with stone sarcophagi and the other five with brick sarcophagi). Besides these graves, there are several mentions of older discoveries in this area: stone and brick sarcophagi in 1860 (?) and 1873 and other brick sarcophagi in 1911-1912. ${ }^{26}$

2."Zânelor" Hill.

On the neighbouring hill called "Zânelor" Hill (Tündérhegy ${ }^{27}$ ) located East of "Șuia", a cluster containing twenty graves ${ }^{28}$ was found in 1906. All of the defuncts were laid in simple pits, without any type of sarcophagus. Each one had a coin, a lucerna and an unspecified ceramic recipient. ${ }^{29}$ Unfortunately, we do not have a sketch or more info's about this cluster.

3."Pardeiului" Valley.

Situated between the aforementioned hills, "Pardeiului" Valley is also an area who belongs to the funerary landscape of Poitaissa. Between 1905 and 1906, the Hungarian scholars found in a relatively small perimeter 11 graves. Just three of them had brick sarcophagi; the other 8

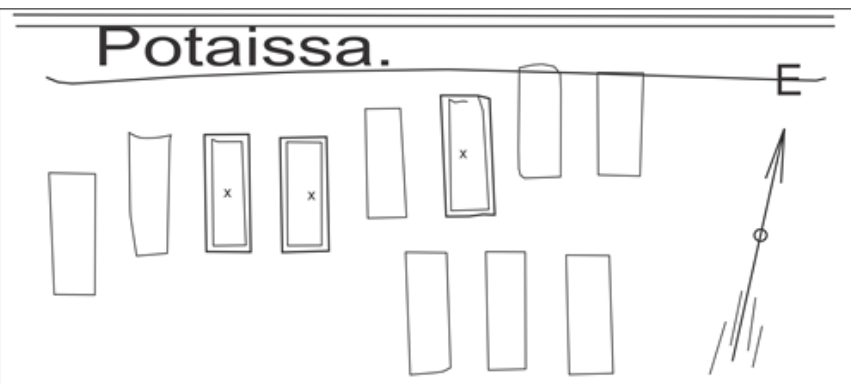

Fig. 1. "Pardeiului" Valley graves. (Redrawn after BAJUSZ et all. 2005, 775)

had a simple inhumation. ${ }^{30}$ In this case, we have a situational plan of the cluster but no info about inventory or skeletons.

At "Valea Sândului" (4) located between „Zânelor" Hill and castra legionis, on the property of S.Miklós and D.Lengel were found human bones and funerary monuments ${ }^{31}$. At "Csillagmál" (5), which is an extension to the west of "Zânelor" Hill $^{32}$, several funerary monuments had been found together with a bowl used in funerary context. ${ }^{33}$ This area is probably a part of the western burialscape of the city.

A little bit North-East from "Zânelor" Hill in the point named "Furdulușeni" (6), another grave cluster was found in 2002. This one was composed of 5 graves $^{34}$ (one grave with brick sarcophagus, one grave with inhumation but with an undetermined type (because of the damage caused by the bulldozer), two bustum-type incineration and one ustrinumtype incineration).

From this point to South, in the place named "Târgul de Vite" (7) situated on the right bank of Sândului Valley, a

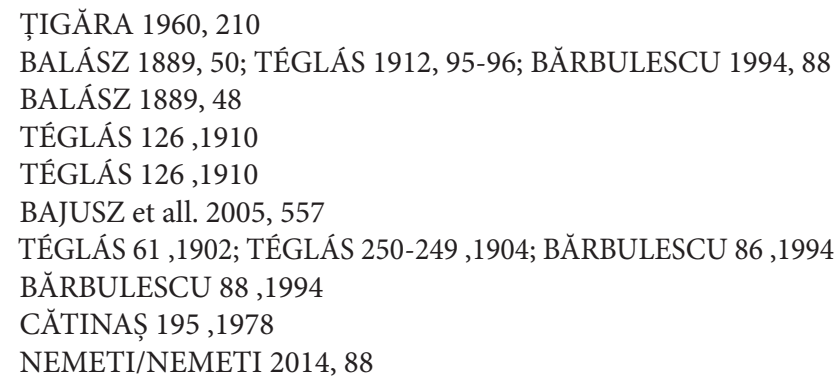




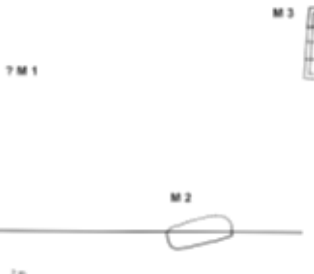

are 59 graves scattered in the perimeter of castra legionis, probably also in the perimeter of the municipium and near the Roman road. Is there any logic in these clusters? Can we draw an inference about the physical boundaries of this funerary landscape?

"Șuia" and "Zânelor" hills with "Pardeiului" Valley between them are considered a distinct funerary space, commonly known as "western necropolis" 46 . On the other hand, the graves from the central area of Turda are recently considered by S. Nemeti another distinct funerary space named by him "the northern necropolis". ${ }^{47}$

This fragmentation of the funerary space is mainly the result of isolated grave cluster studies rather than a full overview of the burialscape.

In my opinion, (see Fig. II) there is just one funerary space, beginningin the hills area and "Csillagmál”, intersecting the Roman road approximatively at "Furdulușeni" and "Târgul de Vite", continuing on the right side of the Roman road in the central area of the modern city. Therefore, it is a possibility to exist a large and unitary necropolis, a funerary space passing in front of the civil settlement and in front of castra legionis. By the fact that this necropolis is an urban one, it is normal to be placed on city's outskirts, outside its found ${ }^{38}$ On the "Jokái" street (the old name of the street), in 1904, another brick sarcophagus saw the daylight. ${ }^{39}$ Not too far from this point, on Rósza Street (nowadays vanished) at Lajos Bardocz's wedge, two brick sarcophagi and a stone sarcophagus were found during some diggings for the groundwork of the house. ${ }^{40}$

In 1907, in the garden of Finta house, the property of Jósika, an old house was demolished. During other works in this area, an (unspecified) number of Roman graves were reported. However, a brick sarcophagus was kept intact. ${ }^{41}$

Rákóczi Street (the old name of the street) is also part of the necropolis. Here, in 1912 a brick sarcophagus was found, destroyed later by the workers. ${ }^{42}$ Also on Labirintus Street (Nouă Street), in the same year another brick sarcophagus was found. ${ }^{43}$

In 1984 during the civil works for A I building on the Libertății Street, workers brought to the surface two brick sarcophagi. ${ }^{44}$ Recently two more chalk sarcophagi were found in this perimeter, on Titulescu Street. ${ }^{45}$

By now, these are all the funerary findings (beside funerary monuments, statues and inscriptions) in this area, North of Arieș River. There

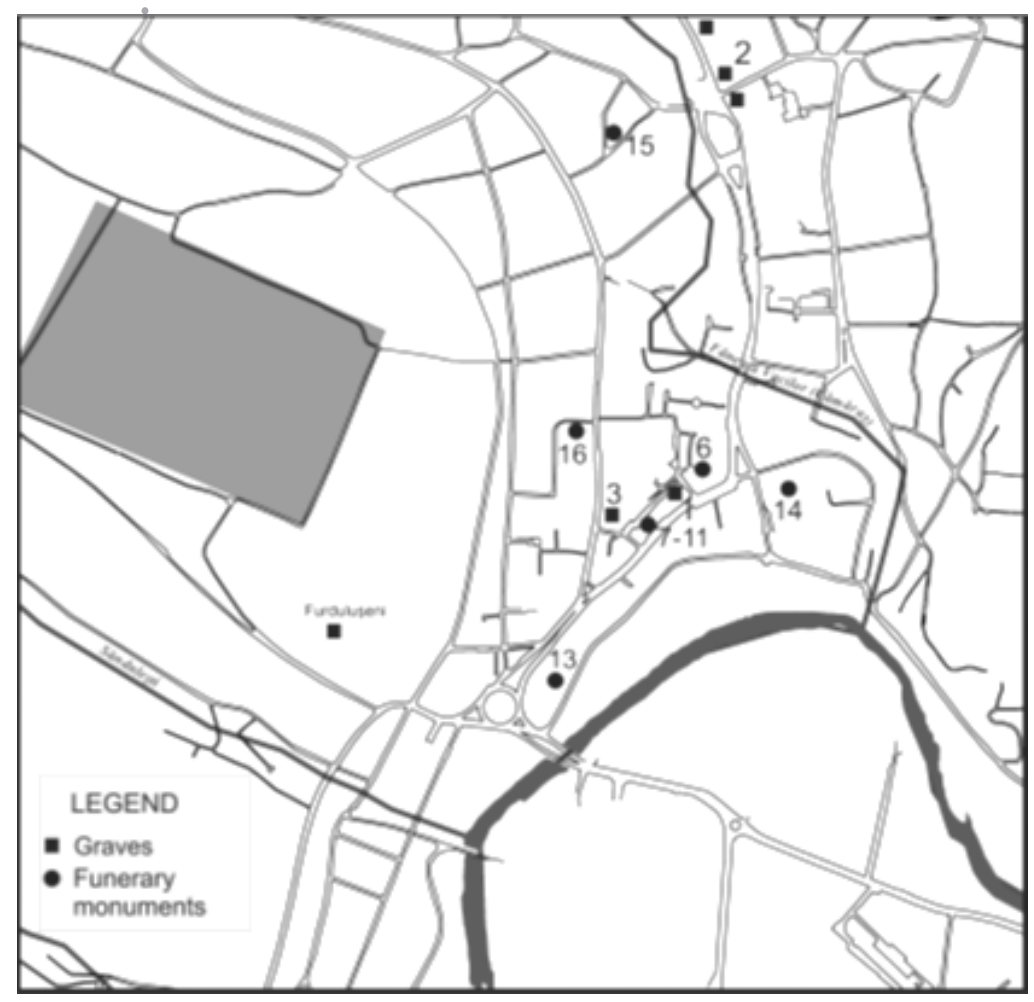

Fig. 3. The "northern necropolis" (after NEMETI/NEMETI 2014, 88)

35 BAJUSZ 1980, 385

36 BALÁSZ 1889, 44; TÉGLÁS 1904, 250; BĂRBULESCU 1998, 87

37 BAJUSZ et all. 2005, 855-856

38 TÉGLÁS 413-410,1904

39 BAJUSZ et all. 2005, 856

40 BAJUSZ et all. 2005, 886-887

${ }_{41}$ TÉGLÁS 3601908

${ }_{42}$ BAJUSZ et all. 2005, 885

43 BAJUSZ et all. 2005, 893-894

${ }_{44}$ BĂRBULESCU 1994; CĂTINAȘ 98-89 2011

${ }_{45}$ I express my gratitude to Dr. Dan Matei for providing me with the information. walls ${ }^{48}$, as a communal place for burials.

Probably at "Furdulușeni" and "Târgul de Vite" the necropolis is bordering the Roman road generating a usual funerary landscape ${ }^{49}$, by accompanying the road a while. ${ }^{50}$ Regarding the "isolated" grave cluster from the perimeter of Avram Iancu Street (northern part of the modern city),

\footnotetext{
${ }^{6}$ ŢIGĂRA 1960, 210-211; BĂRBULESCU 1994, 87

7 NEMETI/NEMETI 2014, 88

48 TOYNBEE 1971, 73

49 The so called "roadside cemeteries"

50 TOYNBEE 1971, 73-74
} 
it can be a distinct funerary area in connection with another activity centre (probably canabae legionis). I called this cluster "isolated" mainly because there is by now a lack of funerary findings in the area between the town center and the northern part of the city.

Another important aspect is the typological composition of the burialscape of the necropolis in the terms of percentage analyses. This burialscape contains five types of graves: simple inhumation, inhumation in brick sarcophagi, inhumation in stone/chalk sarcophagi, incineration ustrinum-type and incineration bustum-type. There are 59 graves (grouped in clusters or scattered within the necropolis)

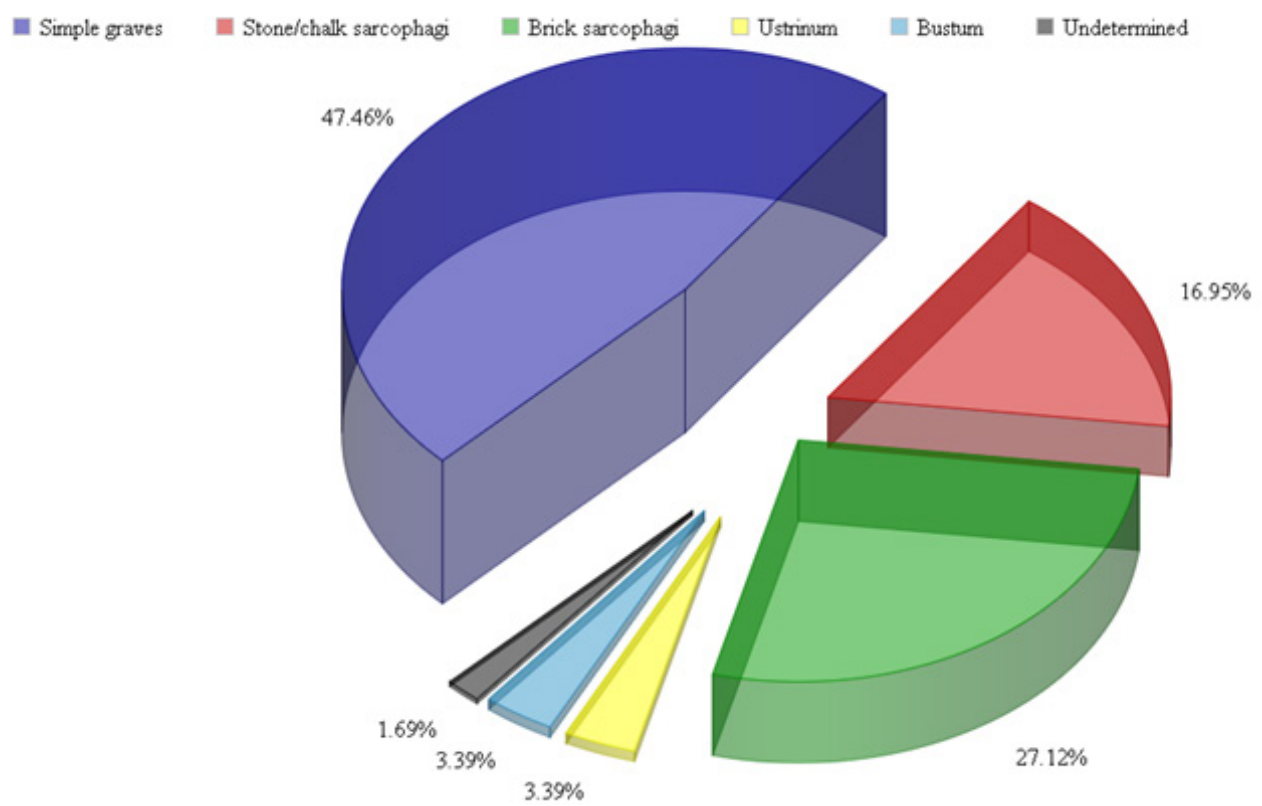
of which 28 (47.46\%) are with simple inhumation, 16 (30.51 \%) with brick sarcophagi, 10 (13.56 \%) with stonelchalk sarcophagi, 2 (3.39\%) incineration ustrinum-type, 2 (3,39 $\%)$ incineration bustum-type and one undetermined. ${ }^{51}$ What conclusions can we draw from these results?

After this analyses there are some aspects regarding the burialscape that we have to pay attention. The percentage difference between the simple inhumation graves and brick/ stone sarcophagi is quite $\mathrm{big}^{52}$ and on the other hand, the simple graves are fund within the same area at "Pardeiului" Valley and "Zânelor" Hill. This type of inhumation is known as the simplest and the humblest form, unadorned by any structures with a simple marker (stone, wood or clay pot) at ground level. ${ }^{53}$

There is a connexion between the treatment provided for the dead and the social status owned in community ${ }^{54}$ therefore a study focused on a funerary area must reflect the social stratification of the living. ${ }^{55}$ As J. Tainter once said, a key in determining the social status of the dead is to observe the energy invested in the funerary ritual. ${ }^{56}$ The possibilities of community to invest in a funerary pomp are directly proportional with its economic development. ${ }^{57}$ Therefore it is a possibility to correlate the simple inhumation graves from

${ }_{51}$ This percentage reflects the current state of funerary findings (graves) but it can be changed with each new discovery. Besides these graves, for which we know the year of discovery, the place, the number(s) and the description, there are several more graves just mentioned, without a description or a certain number. In this case, the graves are not cataloged but only indicated on a general plan.

${ }_{52}$ It is required to take into account the chance of finding one type or another since there are incidental findings.

53 TOYNBEE 1971,

54 AMES 2007, 497

${ }_{55}$ AMES 2007, 497

56 TAINTER 1975, 1-15

57 As a rural settlement with a nucleus of colonists, it is normal that the economy of early phase to be at a lower level, therefore, the investment in a funerary commemoration must have in my opinion a lack of glitter.

"Zânelor" Hill and "Pardeiului" Valley with the rural phase of Patavissensium vicus, the first stage of the settlement, because of the lower level of the economic process, a normal fact in case of a newly created settlement without a solid municipal aristocracy having an available significant wealth. ${ }^{58}$

An inscription from Ulpia Traiana Sarmizegetusa tells us that for the funerals of Quintus Ianuarius Zosimus collegium fabrum paid 400 denarii. ${ }^{59}$ We do not know exactly if this price covered all costs related to burial or just the funerary monument ${ }^{60}$, but it represents a glimpse of the "funeral environment" most likely present at Potaissa at a certain period.

Unfortunately there is no solid arguments yet to date more precisely the first necropolis because of the precarius excavations and mainly because majority of the graves are robbed and the possibility to clarify the chronological context of different clusters is almost reduced to zero. As a scenario based on graves typology aforementioned, the early phase of the necropolis is possible to be in the area of "Zânelor" Hill and "Pardeiului" Valley area, started sometime at the beginning of the $2^{\text {nd }}$ century A.D. and continuing to the central town and "Șuia" Hill during the same century.

From the information that we have, it is impossible to determine if the necropolis had a systematic layout or not. In the case of "Furdulușeni" graves for example, it seems there is no spatial patterning. At "Pardeiului" Valley it seems that there is some logic in the disposal of the graves with a regular distance between them. Anyway, until a large-scale excavation is made, this question remains open.

At the moment, we do not have another information and unfortunately, in this phase we cannot tell more about

\footnotetext{
58 ARDEVAN 1998, 255

59 CIL III 2413 Text: D(is) M(anibus)/ Q(uinto) Ianuario/ Zosimo vix(it)/ ann(is) XXXV/ et Ianuariae/ Candidae vix(it)/

ann(is) XXX/ Q(uintus) Ianuar(ius) Agathan/gelus fil(is) piiss(imis) posuit/ ad funus autem Zosimi/ et titulo contulerunt/ colleg(ium) fabr(um) (denarios) CCCC/ Q(uintus) Ia(nuarius)

${ }_{60}$ BĂRBULESCU 2003, 85
} 


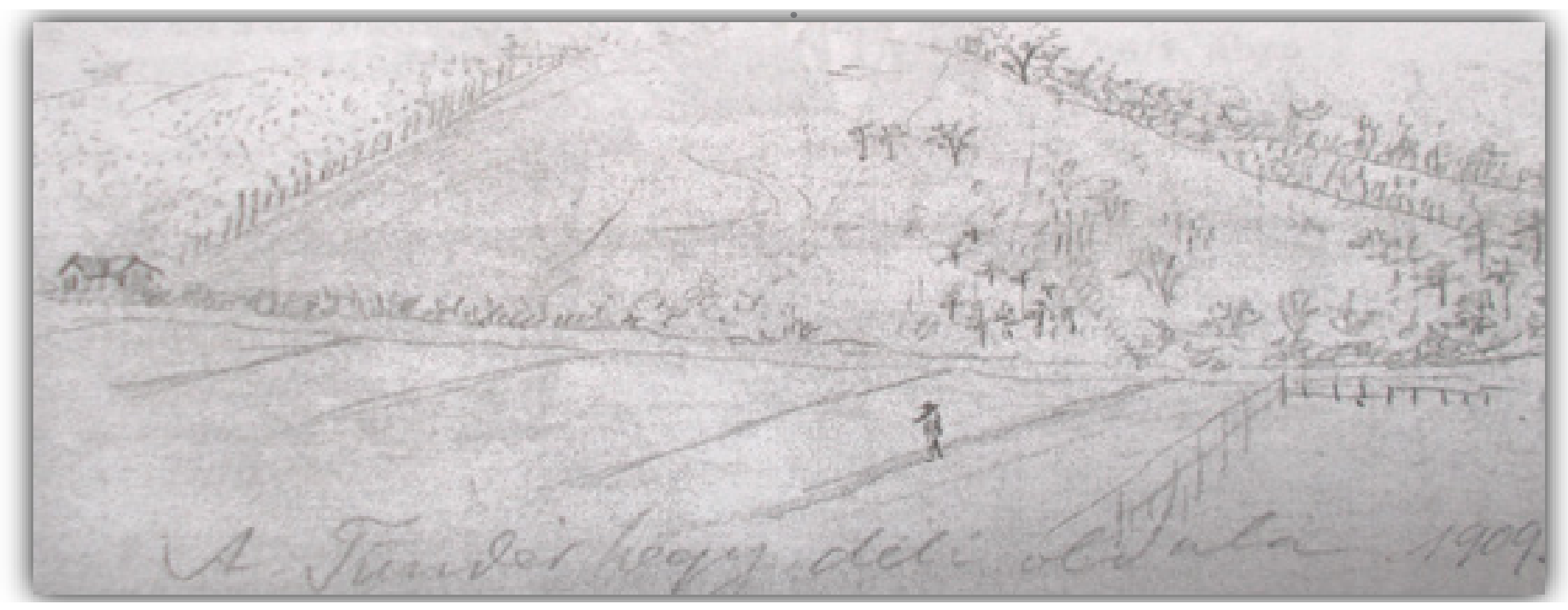

Fig. 5. Tündérhegy-"Zânelor" Hill/December 1909 in a sketch of I. Téglás (after BAJUSZ et all 2005, 727)

the burialscape situated North of Arieș River.

\section{The second necropolis.}

Beside the first burial place analysed above, the archaeological finds outlined over time a second one, placed at the border of Turda, on the left bank of Arieș River at a considerable distance from the Roman nucleus of Potaissa.

The first Roman graves are found here starting with 1894 until 2006. In contradistinction with the first necropolis, the second one is slightly better documented, every grave cluster having a detailed description and/or a terrain/situational positioning. Proceeding as in the first case, we will make an overview of the clusters in order to observe the particularities of this burialscape.

\section{1."Bodoc"}

The place called "Bodoc" is situated at the intersection of DN 75 (Turda-Câmpeni) with DN 1 (Turda-Aiud) near the obelisk of Ladislau Gedő (WGS 84: N 46³2'39.83" E $\left.23^{\circ} 46^{\prime} 30.92^{\prime \prime}\right)$. Between 1894 and 1895 were discovered here (and recorded) the first Roman graves belonging to the second necropolis of Potaissa. The cluster contained 25 graves: ${ }^{61} 16$ graves with stone/chalk sarcophagi, one grave with brick sarcophagus and 8 undetermined graves. ${ }^{62}$ In 1904, on the land property of Wolff, near "Bodoc", a stone sarcophagus and cinerary urn were found. In 1911 during the construction of the old railway (Turda-Abrud) the

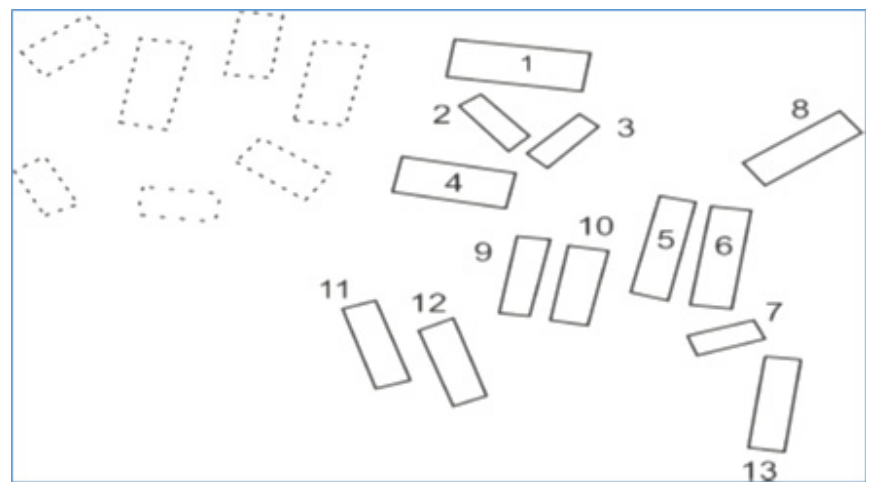

Fig. 6. The plan of "Bodoc" graves from 1894-1895 (Redrawn after TÉGLÁS 1896, 66)

61 VOLENSKY 1895, 72; TÉGLÁS 1896, 65-68; FLOCA 1941, 21-24, 41

62 Probably brick sarcophagi but Téglás does not mention exactly. workers found also some Roman graves. ${ }^{63}$

\section{2. "Mihai Viteazu"-military barracks}

The military barracks are situated approximatively $200 \mathrm{~m}$. East of "Bodoc". In 1936, during the construction of the first barrack and in 1937 during the diggings for a duct between the second barrack and DN 1 (Turda-Aiud), 21 graves were found: ${ }^{64} 12$ graves with stone sarcophagi, 8 graves with brick sarcophagi and a grave with a sarcophagus made from reused monuments.

\section{3. "Râtul Sânmihăienilor"}

Râtul Sânmihăienilor" is the arable land between Arieș River and the military baracks, crossed by the so-called "Bădenilor" Road that connected Mihai Viteazul commune with the actual DN1 road (Turda-Aiud). In this perimeter, at the distance of about 350-400 m. from Turda-Aiud road in 1956 after some civil works, were discovered 5 graves: ${ }^{65} 1$ grave with stone sarcophagus, 2 graves with brick sarcophagi, 1 grave with a sarcophagus made from slabs and 1 grave with sandstone walls and a vaulted roof made from sandstone slabs. After some years, in 1964, 3 more stone sarcophagi were found in the same perimeter. ${ }^{66}$

\section{4. "Uzina de apă" - the water plant}

The eastern part of the necropolis ${ }^{67}$ (from what we know so far) is situated in the perimeter of the water plant of Turda (water plant coordinates WGS 84: N 46³2'37.96" E $\left.23^{\circ} 47^{\prime} 08.48^{\prime \prime}\right)$. Over several years and on various occasions Roman graves were brought to surface. In 1969, 5 Roman graves were found after a short archaeological survey. ${ }^{68}$ In 1978 , other 14 graves were found within the abovementioned area during some building activity. ${ }^{69}$ The 63 I.TÉGLÁS in Aranyosvidék, 29 April 1911 apud. ȚIGĂRA 1960, 210, BĂRBULESCU 1994, 88

${ }_{64}$ RUSSU 1941, 333-338

${ }_{65}$ ȚIGĂRA 1960, 197-199

${ }_{66}$ MITROFAN 1969, 521

${ }^{67}$ MILEA/HOPÂRTEAN/LUCA 1978, 201; BĂRBULESCU 1994, 88 ${ }_{68}$ MILEA/HOPÂRTEAN/LUCA 1978, 201-206. Republished with photos, sarcophagi drawings and osteological analyses in WOLSKA 1999, 244-255

${ }^{69}$ LUCA/HOPÂRTEAN 1980, 115-122 


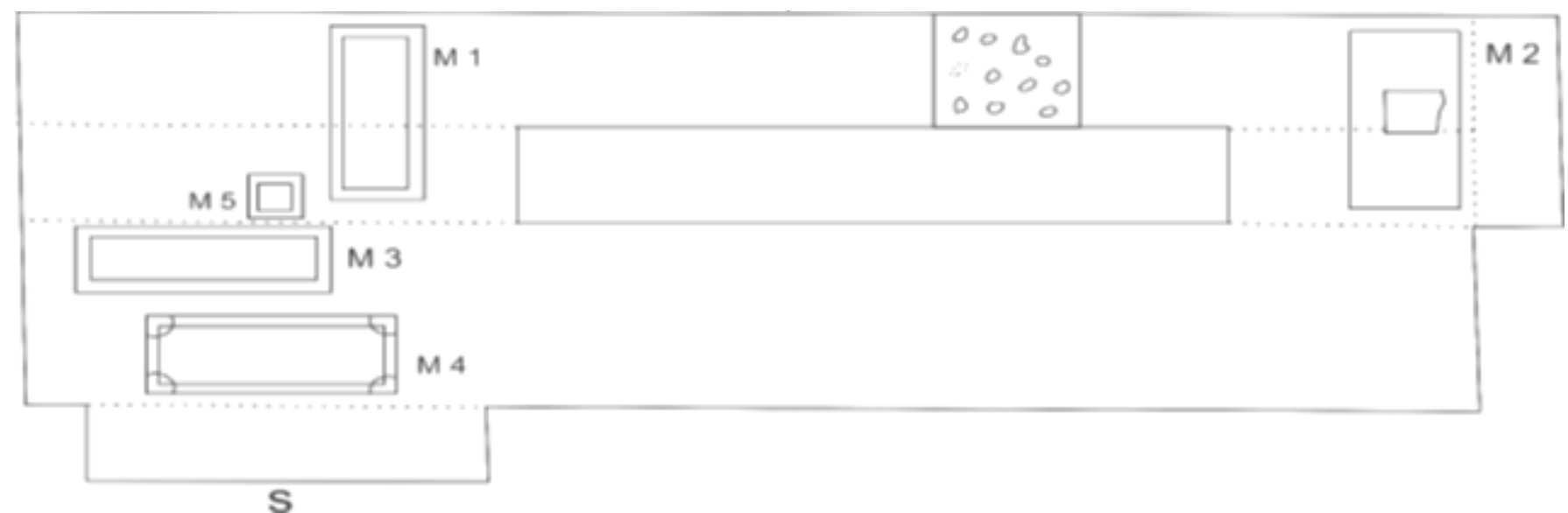

Fig. 7. The plan of the graves found in 1969 at the water plant. (Redrawn after MILEA/HOPÂRTEAN/LUCA 1978, 2006)

last three stone sarcophagi graves were found here in $1985 .^{70}$ The total number of the graves is 22 of which 12 are with stone/chalk sarcophagi, nine are with brick sarcophagi and an incineration-ustrinum type grave (with a cinerary urn imitating a stone sarcophagus).

\section{"Transilvania Highway"}

The last graves from the second necropolis of Potaissa were found during the rescue excavation from Brașov-Borș Highway, on surface of $100 \mathrm{~m}^{2}$. in the sector 2B1-km 9+000$15+000 .{ }^{71}$ The archaeologists found 9 Roman graves ${ }^{72}: 4$ with brick sarcophagi, 3 with chalk sarcophagi, a sarcophagus made from reused monuments and an incineration-strinum type grave.

If the burialscape of the first necropolis was seen fragmented over time, in the case of the second one the scholars recognized the uniformity of it. It was called "the big necropolis", "the southern necropolis" or "the main necropolis of Potaissa"73. As it appears so far, the limits of the (known) burialscape are quite clear and M. Bărbulescu (in his monograph book about Potaissa, from 1994) has drawn them quite accurately. ${ }^{74} \mathrm{He}$ determined (with a

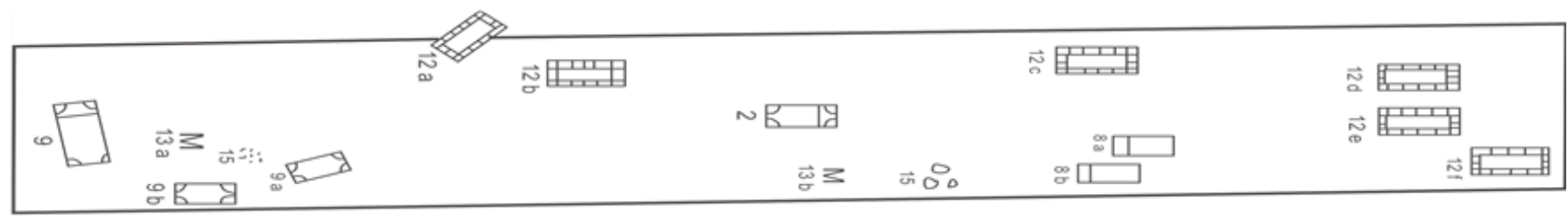

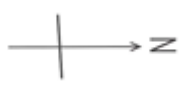

$>$

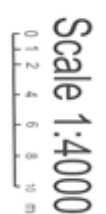

Fig. 8 Plan of the graves found at "Mihai Viteazu" military barracks (Redrawn after RUSSU 1941, 332).

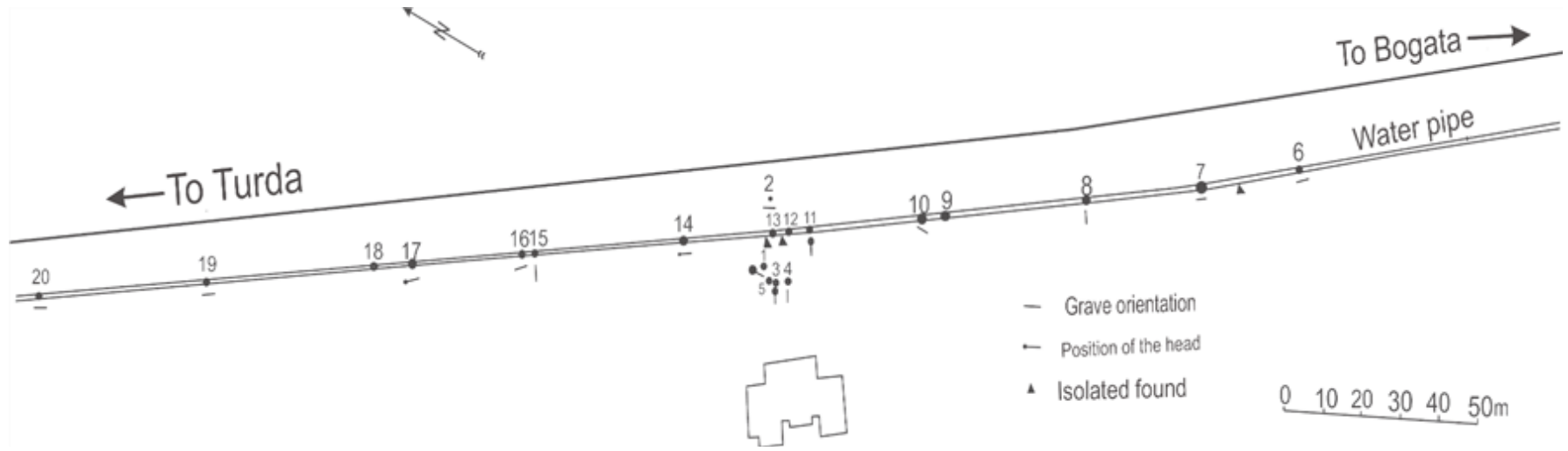

Fig. 9. Plan of the graves found at the water plant in 1978 (Redrawn after LUCA/HOPÂRTEAN 1980, 221).

\footnotetext{
70 BĂRBULESCU 88,1994

71 P̂̂SLARU 3392007

72 PÎSLARU 364-339 2007. It is important to mention that are also 3 migration period graves found within this area whitch overlappsed the roman burial cluster.
}

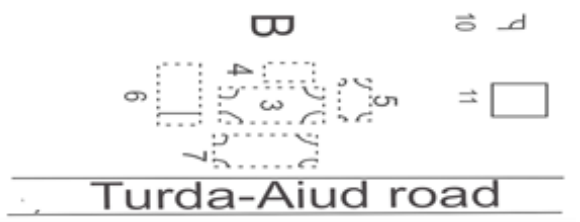




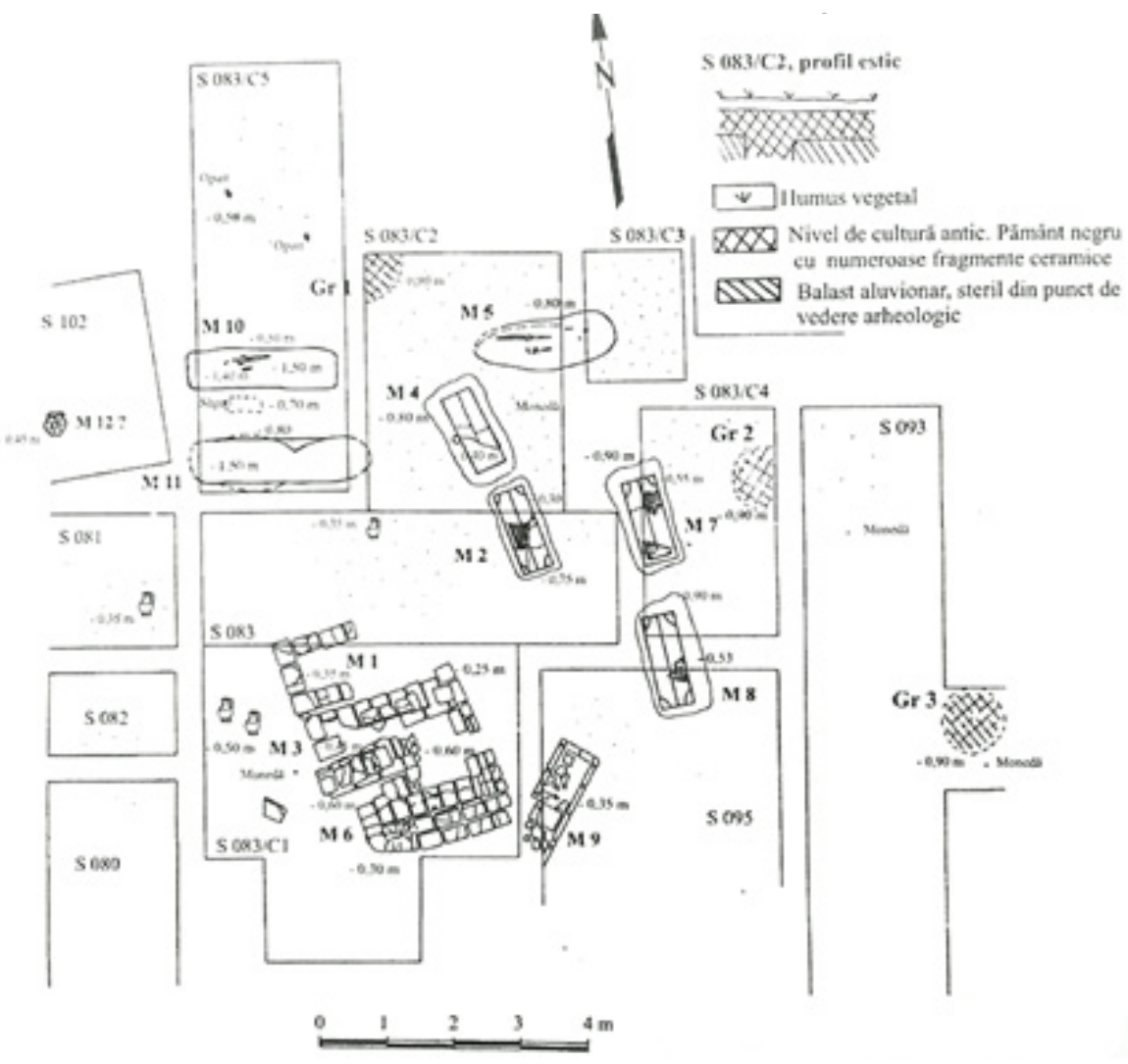

Fig. 10. Plan of the graves found in 2006 during the rescue excavation from "Transylvania Highway" (After PÎSLARU 2007, 347)

little doubt) that the northern point of the necropolis is somewhere near the concrete factory, ${ }^{75}$ but in my opinion we must set the northern point (at least until new graves are found further North) at "Râtul Sânmihăienilor". In the SouthEast the last graves are so far localized in the area of the water plant. ${ }^{76}$ The South-West extremity is marked by the "Transylvania Highway" burial cluster. In the Southern part, the burialscape is possible to continue at least $1 \mathrm{~km}$ south from the military barracks according to a series of brand new aerial photos (see Fig. VI.).

It seems that (as we know so far) the evolution of the burialscape is from North to South, accompanying the Roman road a while. At Turda's water plant (as M.Bărbulescu already noticed ${ }^{77}$ ) the burial cluster is closer to the ancient road, the later evolution of the burialscape being towards Mihai Viteazu commune in the South-West. The aerial photography revealed some crop marks that are possible to be a burial cluster, at approx. $1 \mathrm{~km}$ south from the military barracks (WGS 84: N 46³2'12.71" E 46³2'12.71") theoretically also near the Roman road. Another set of aerial photos from the barrack's area, interpreted using GE-imagery ${ }^{78}$ reveals a new burial cluster, very close from the one discovered in 18941895 at "Bodoc" and from the one discovered at the military barracks. However, this studied area is just a glimpse of the southern necropolis, a phenomenon related to the fact that

\footnotetext{
75 In my oppinion, the unguentarium found in the area of the concrete factory and publish by H.Daicoviciu is not a strong reason to consider the northern limit there. See DAICOVICIU 69157 for the discution.

76 BĂRBULESCU 88,1994

77 BĂRBULESCU 88,1994

78 CZAJLIK, BERECKI, RUPNIK 2014476
}

this is mainly an industrial sector, the construction works generating (until now) the funerary discoveries.

The typological composition of the second necropolis is a little bit different than in the first case. At the moment, 87 graves are known. Forty-eight $(54.55 \%)$ graves are of stone/chalk sarcophagi; 24 (27.27\%) graves with brick sarcophagi; 3 (3.41 $\%)$ incineration-ustrinum type graves, 2 (3.41) graves with sarcophagi made from reused monuments; 2 (2.27 \%) graves of another type ( 1 grave with a sarcophagus made from slabs and 1 grave with vaulted roof); 8 (9.09\%) undetermined graves, 0 graves with simple inhumation and 0 incinerationbustum type graves.

If in the first burialscape the simple inhumations (associated with the poor) are by now the main type, immediately followed by the brick sarcophagi type, and on the $3^{\text {rd }}$ position by stone/chalk sarcophagi, the second burialscape reveals a different image. The main type preferred by society is the inhumation in stone/chalk sarcophagi, some of them being elegantly crafted. ${ }^{79}$ It seems that the simple inhumation does not exist anymore in this area. Therefore, in the manner of Tainter's theory about the energy invested in the funerary ritual, it is a possibility to consider this necropolis belonging to a society with a higher economical level. We do not know if both of the necropolises are used simultaneously or not, but we know for sure that the analyzed perimeter of the southern necropolis is in used in the $3^{\text {rd }}$ century, and also later by a migration period population.

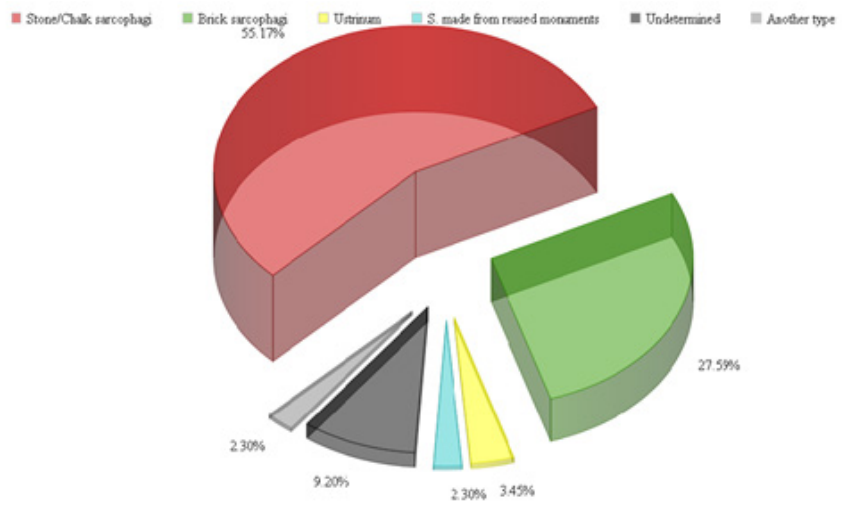

Fig. 11. Pie chart containing percentages of different grave types from the second necropolis of Potaissa.

There is a lack of dating elements within this funerary space (only 5 known coins found in graves ${ }^{80}$ ) but a series of fibulae found in situ can reveal some aspects regarding the

\footnotetext{
79 See WOLSKA 1999, 245-246

80 1 coin of Vespasian, 1 coin of Trajan, 1 coin of L. Verus for Ania Lucilla, the wife of Lucius Verus, 1 coin of Septimius Severus and 1 coin of Gordian III.
} 
chronology of this sector. We know so far 3 fibulae from 3 different burial clusters. The first one was found in 1964 in a stone sarcophagus at "Râtul Sânmihăienilor"81 and bassed on Prötel typology it is a Zwiebelknopffibeln type $1 .^{82}$ The next one was found in 1969 in the cinerary urn from the water plant burial cluster ${ }^{83}$ and based on Cocis typology it is a 39b4c1 type. ${ }^{84}$ The last one was discovered in 1978 in a brick sarcophagus from the water plant ${ }^{85}$ and it is a $39 b 5 c 1 b$ type. ${ }^{86}$ Based on Cocis typology of fibulae from Roman Dacia, the fibulae type 39 are the T-shaped brooches (Scharnierarmfibeln) are generally dated on the $3^{\text {rd }}$ century, until 275 A.D. ${ }^{87}$ Based on Prötel, Zwiebelknopffibeln are dated in the late $3^{\text {rd }}$ century and the beginning of the $4^{\text {th }}$ century A.D. (280-320)

The presence of the sarcophagi made from reused monuments is another element on which we can enframe this sector of the southern necropolis in the $3^{\text {rd }}$ century or in the $4^{\text {th }}$ century after some scholars. ${ }^{88}$ A brick sarcophagus belonging to a child, made from brick stamps with L V M ${ }^{89}$ (Legio Quinta Macedonica) found at "Râtul Sânmihăienilor" it could be dated also in the last quarter of the $3^{\text {rd }}$ century, probably after the withdrawal of the legion from Potaissa.

Identifying these elements (see Fig. IV), we can say that the southern necropolis, at least this sector of it, ${ }^{90}$ could be the last phase of the Roman burials horizon from Potaissa.

Neither in the case of the first necropolis, nor in the case of the second one, we cannot observe a clear distribution pattern or spatial relation between graves. In the case of the burial cluster from "Transylvania Highway", those three adjoined brick sarcophagi (see Fig.10) could indicate a relationship between deceased. Anyway, in a necropolis exists either situations where one can see a logic in the alignments of the tombs or not. As Toynbee said: "The alignments of the various groups of tombs in a single cemetery are, however, sometimes so different from one another that we can only deduce the absence of any public control of a cemetery's growth and of any overall rational planning of it as an entity."91

In conclusion, these are the main problems regarding the funerary spaces of Potaissa. Unfortunately, the fragmented information and the lack of systematic research, at least in the southern necropolis, restricts the possibilities of understanding the funerary landscapes and raises some questions that can be answered without a proper strategy. Any burial place has its secrets and the possibility to find them is conditioned by a proper research strategy. 146 graves is a small number for a civil and a military Roman centre as Potaissa is, therefore in my opinion, an excavation

81 MITROFAN 1969, 521

82 PRÖTEL 1988, 350-353

83 WOLSKA 1999, 248

${ }^{84}$ COCIȘ 2004, 152

85 LUCA/HOPÂRTEAN 1980, 119

86 COCIS 2004, 153

${ }^{87}$ COCIȘ 2004, 154

${ }_{88}$ For the dating of the sarcophagi made from reused monuments in Dacia see HICA-CÂMPEANU 1977, 221-237; HOREDT 1979, 211 214; PROTASE 2000, 131-134

89 ȚIGĂRA 1960, 198-199

90 We do not know exactly if the crop marks discovered south of military barracks are a grave cluster, and if so, it is a hypothesis whether it may belong to the southern funerary landscape or not.

91 TOYNBEE 1971, 74 focused strictly on the burial places is the starting point for a better understanding of the necropolises and their evolution in time and space.

\section{REFERENCES}

\section{AMES 2007}

Ames, K.,M.,The archaeology of Rank. In: Bentley, R.,A./ Maschner, H., D., G./Chippendale (eds.) Handbook of Archaeological Theories (Lanham: AltaMira Press), 487-513

\section{ARDEVAN 1998}

Ardevan, R, Viața municipală în Dacia Romană (Timișoara: Mirton)

\section{BAJUSZ 1980}

Bajusz,I., Colecția de antichități a lui Téglás István din Turda, Acta Musei Porolissensis 4, 367-394

BAJUSZ et alli 2005

Bajusz, I. (ed)Téglás Istvan Jegyzetei. Régészeti Feljegyzések I/2 (Cluj-Napoca: Scientia)

BALÁZS 1889

Balázs, O., Torda város és környéke (Budapesta)

\section{BĂRBULESCU 1987}

Bărbulescu, M., Din istoria militară a Daciei Romane vol. I. Legiunea a V Macedonica și castrul de la Potaissa (ClujNapoca: Dacia)

BĂRBULESCU 1994

Bărbulescu, M., Potaissa: studiu monografic (Turda)

\section{BĂRBULESCU 2003}

Bărbulescu, M., Ritualuri periodice. In: Bărbulescu, M., (ed.), Funeraria DacoRomana (Cluj-Napoca: Presa Universitară Clujeană)

\section{CĂTINAS 1978}

Cătinaș, A., Noi descoperiri pe Dealul Zânelor, Acta Musei Napocensis 15, 195-200

\section{CĂTINAS 2011}

Cătinaș, A., Représentations de la scène du festin funéraire sur les monuments de Potaissa. In: Piso, I./Bolindeț, V./ Varga, R./Mustață, S./Beu-Dachin, E., (eds.), Scripta Classica. Radu Ardevan sexagenario dedicate (Cluj-Napoca: Mega), 89-98

\section{COCIȘ 2004}

Cociș, S., Fibulele din Dacia Romană (Cluj-Napoca: Mega)

\section{CZAJLIK/BERECKI/RUPNIK 2014}

Czajlik, Z./Berecki, S./Rupnik, L., Aerial Geoarchaeological Survey in the Valleys of the Mureş and Arieş Rivers (2009-2013), Dissertationes Archaeologicae ex Instituto Archaeologico Universitatis de Rolando Eötvös nominatae Ser. 3. No. 2., 459-483

\section{FLOCA 1941}

Floca, I., Sisteme de înmormântare in Dacia Superioară Romană, Sargetia 2, 1-116

HICA-CÂMPEANU 1977

Hica-Câmpeanu, I., Cu privire la unele morminte Romane tîrzii de la Napoca, Acta Musei Napocensis 14, 221-237

\section{HOREDT 1979}

Horedt, K., Die städtischen Siedlungen Siebenbürgens in spätrömischer Zeit, Sargetia 14, 203-217

LUCA/HOPÂRTEAN 1980

Luca, C.,/Hopârtean, A., Noi descoperiri in necropola sudică a Potaissei, Potaissa II. Studii și comunicări, 115-122

MILEA/HOPÂRTEAN/LUCA 1978

Milea, Z./Hopârtean, A./Luca, C., Noi contribuții privind necropola Romană de la Potaissa, Acta Musei Napocensis 15, 201-206

\section{MITROFAN 1969}

Mitrofan, I., Descoperiri arheologice la Potaissa (Turda), Acta Musei Napocensis 6, 517-723 


\section{NEMETI/NEMETI 2014}

Nemeti, S./Nemeti, I., Civil space and municipal statutes in Potaissa, Archäologische Beiträge. Gendenkschrift zum hundertsten Geburtstag von Kurt Horedt, 85-98

PISO 2014

Piso, I., Sur le statut municipal de Potaissa. In: Cocis, S. (ed) Archäologische Beiträge. Gendenkschrift zum hundertsten Geburtstag von Kurt Horedt, 69-75

PÎSLARU 2007

Pîslaru, M., Un grup de morminte Romane si post-romane de la Potaissa. In: Dacia Felix. Studia Michaeli Bărbulescu Oblata (Cluj-Napoca: Tribuna), 339-364

PROTASE 2000

Protase, D., Autohtonii în Dacia.II.Dacia postRomană până la slavi (Cluj-Napoca: Napoca Star)

PRÖTEL 1988

Prötel, Ph., M., Zur Chronologie der Zwiebelknopffibeln, Jahrbuch des Römiche-Germanischen Zentralmuseums Mainz $35,347-372$

RUSSU 1941

Russu, I.,I., Descoperiri arheologice la Potaissa, Anuarul Institutului de Studii Clasice, 319-340

\section{TAINTER 1975}

Tainter, J., A., Social inference and mortuary practices: An experiment in numerical classification, World Archaeology 7, 1-15

TÉGLÁS 1896

Téglás, I., A keresztesmezei sárkophagokró, Archeologiai
Értesítő 16, 65-68

TÉGLÁS 1904

Téglás, I., A Potaissa maradványaiban 1903-ban és 1904ben talált tárgyakról és feliratokról, Archeologiai Értesítő $24,410-413$

\section{TÉGLÁS 1908}

Téglás, I., Tordán és mészkon talalt romái feliratokról, Archeologiai Értesítő 28, 360-361

\section{TÉGLÁS 1910}

Téglás, I., .Romok és leletek a Tordai Tünderhegye, Archeologiai Értesítő 30, 123-130

\section{TOYNBEE 1971}

Toynbee, J., M., C., Death and Burial in Roman World (U.S.A.: Cornell University press)

\section{ȚIGĂRA 1960}

Țigăra, I., Necropolele de la Potaissa, Probleme de muzeografie, 195-211

VOLENSKI 1895

Volensky, G., Kókoporsókról a keresztes mezőn, Archeologiai Értesítő 15, 72-73

WOLSKA 1999

Wolska, W., Varia Romana.I .Ein Bisher unbekannter Sarkophag-Typ aus Potaissa/Dacia Superior. In: Boroffka, N./Soroceanu, T. (eds.), Transsilvanica. Archäologische Untersuchungen zur älteren Geschichte des südöstlichen Mitteleuropa. Gedenkschrift für Kurt Horedt. Internationale Archäologie [Studia honoraria 7] (Rahden/Westf.: Marie Leidorf GmbH), 241-264.. 